\title{
Sobre a Eliminação da Metafísica por meio da Análise Lógica da Linguagem de Carnap*
}

\author{
P.M.S. Hacker*
}

1. O Pano de Fundo: o Manifesto do Círculo de Viena

O artigo de Carnap "A Eliminação da Metafísica por meio da Análise Lógica da Linguagem" foi publicado em 1931/2 na Erkenntnis. Ele era uma versão revisada de uma conferência que Carnap tinha dado em Novembro de 1930 na Universidade de Varsóvia. Ao longo dos anos, esse artigo iconoclasta atraiu atenção considerável. Ele foi traduzido para o francês (1934), português (1945), italiano (1950), inglês (1959) e espanhol (1959). No volume de Schilpp A Filosofia de Rudolf Carnap (1963) na série $A$ Biblioteca dos Filósofos Vivos, o antigo colega de Carnap no Círculo de Viena, Philipp Frank, observou que "Entre os numerosos escritos de Carnap provavelmente nenhum teve um efeito tão gran-

* Este artigo foi escrito originalmente em inglês para ser publicado na Deutsche Zeitschrift für Philosophie, em 2000. Agradecemos ao autor e à revista por permitirem a sua tradução e a sua publicação em português.

** St. John's College, Oxford. Tradução de Plínio Junqueira Smith (Universidade Federal do Paraná e Pesquisador do CNPq). 
de e amplo quanto [esse] artigo" Era indubitavelmente uma contribuição importante para as doutrinas daquela mais influente das escolas de filosofia do século XX - o positivismo lógico ou, menos enganosamente, "empirismo lógico" Com efeito, ele influenciou grandemente a primeira formulação inglesa das doutrinas do Círculo de Viena, a saber, a obra Linguagem, Verdade e Lógica (1936), de A.J. Ayer, cujo primeiro capítulo foi intitulado "A Eliminação da Metafísica" e apoiava-se pesadamente no artigo de Carnap.

É digno de nota que as idéias fundamentais desenvolvidas no artigo já tinham sido incorporadas no Manifesto de 1929, A Concepção Científica do Mundo: o Círculo de Viena, escrito para o congresso da Sociedade Ernst Mach e da Sociedade de Berlim para a Filosofia Empírica em setembro de 1929, e dedicado a Moritz Schlick. O manifesto foi assinado por Hahn, Neurath e Carnap (apesar de aparentemente Feigl e Waismann terem escrito partes dele, e de Hahn ter pouco a ver com a redação). A página inicial do Manifesto já traça os rumos do Círculo para uma cruzada anti-metafísica: o espírito da concepção científica do mundo é um herdeiro do Iluminismo e dedicado à erradicação da metafísica. A rejeição, baseada em certos princípios, da metafísica é rastreada até figuras do Iluminsimo como Hume e Voltaire ${ }^{(1)}$, e a seus sucessores tais como Bentham, Mill e Comte, bem como a figuras mais recentes em Viena, incluindo Mach e Boltzmann.

A seção do Manifesto intitulada "A Concepção Científica do Mundo", que contém a principal declaração anti-metafísica de princípios, leva a marca de Carnap. Diz-se nela que o objetivo da Concepção Científica do Mundo é a ciência unificada: ligar e harmonizar as realizações dos investigadores individuais nos vários campos da ciência. Donde ela se esforça por um sistema neutro de simbolismo e um sistema total de conceitos. Os problemas tradicionais da filosofia são ou pseudo-problemas ou, com efeito, problemas empíricos a serem resolvidos pela ciência. A tarefa da fi- 

"a base primária do mundo é o inconsciente" ou "Há uma enteléquia, que é o princípio diretor no organismo vivo", são carentes de significado (meaningless) - se alguém os considera como o metafísico quer que eles sejam considerados. Eles não dizem nada, mas expressam um certo estado de espírito ou atitude em relação à vida - uma atitude mais adequadamente expressa pela poesia ou música.

Dada a ubiqüidade das doutrinas metafísicas, o impulso e a ilusão metafísica exigem explicação. De acordo com o Manifesto, três espécies diferentes de explicação podem ser exploradas: psicológica, sociológica e lógica. As duas primeiras foram tentadas pela psico-análise e pela teoria marxista da super-estrutura ideológica. A terceira foi levada adiante para um estágio mais avançado pela clarificação das origens lógicas da aberração metafísica nas obras de Russell e Wittgenstein. Dois erros lógicos básicos são evidentes. O primeiro consiste na confiança excessiva nas formas logicamente enganosas da linguagem ordinária, que, por exemplo, usa a mesma parte da fala, o substantivo, para coisas, qualidades ("dureza"), relações ("amizade") e processos ("sono"), levando alguém a uma indevida reificação ou hipostatização. O segundo consiste na idéia de que o puro pensamento sozinho pode produzir conhecimento genuíno sobre o mundo. Mas a investigação lógica mostra que todo pensamento e inferência não consiste em nada senão na transformação tautológica de proposições. A idéia de que há alguma proposição kantiana sintética a priori é equivocada - a razão pura sozinha não pode adquirir conhecimento do mundo. Donde também afirmações de realismo e idealismo sobre a natureza da realidade ou idealidade do mundo externo serem carentes de significado. Elas são carentes de significado porque são inverificáveis. Antes, "alguma coisa é 'real' por meio de sua incorporação à estrutura total da experiência"

O Manifesto antecipa "A Eliminação da Metafísica por meio da Análise Lógica da Linguagem" de Carnap. Ele também pinta 
seus princípios em uma tela muito mais ampla. Pois somente uma pequena parte do programa que ele tão ousadamente proclama foi realizado naquele artigo. Algumas partes já tinham sido executadas no artigo de Carnap de 1928, "Pseudo-Problemas na Filosofia: o Heteropsicológico e a Controvérsia do realismo", outras foram tentadas depois que Carnap adotou seu "Princípio da Tolerância na Lógica", em A Sintaxe Lógica da Linguagem (1934), e ainda outras, novamente com alguma mudança de perspectiva, no artigo posterior, e defensavelmente mais profundo, "Empirismo, Semântica e Ontologia" (1950).

\section{O argumento de "A Eliminação da Metafísica"}

Ao longo da história da filosofia, Carnap observou, houve numerosos críticos da metafísica. Alguns declararam que a metafísica é falsa, uma vez que ela contradiz o conhecimento empírico; outros sustentaram que ela é incerta, uma vez que ela transcende os limites do conhecimento possível; outros ainda sustentaram que ela é estéril e irrelevante para os problemas da vida humana. Mas o desenvolvimento da lógica moderna tornou possível dar uma resposta mais precisa à questão da validade da metafísica. Pois a análise lógica mostra que os proferimentos metafísicos são carentes de significado - eles são pseudo-enunciados. Pseudo-enunciados são seqüências de palavras que parecem expressar um enunciado mas na realidade não fazem isso, seja porque elas contém uma palavra que parece ser significativa mas não é, ou porque, apesar de elas constituírem uma sequiência de palavras significativas, elas são mal-formadas, isto é, elas não estão de acordo com a sintaxe lógica da linguagem.

Uma palavra " $a$ " é significativa se e somente se: em primeiro lugar, sua sintaxe foi determinada, isto é, seu modo de ocorrên- 
sequer especifica sua sintaxe, isto é, seu modo de ocorrência na sentença elementar " $x$ é um Deus" - pois a categoria sintática da variável não é especificada. O uso teológico da palavra equivoca entre o uso mitológico (que torna enunciados teológicos empiricamente verificáveis ou falseáveis) e o uso metafísico (que os torna carentes de significado). Outras frases que ocorrem na metafísica, tais como "o Absoluto", “o Incondicionado", "o Infinito", "o ser do ser" "coisa em si mesma", "espírito absoluto”, "espírito objetivo", "ser-em-e-para-si-mesmo"etc. são igualmente desprovidas de significado.

Pseudo-enunciados formados a partir de palavras significativas são possíveis nas linguagens naturais porque a sintaxe gramatical é imperfeita logicamente - para os propósitos da boa formação ela traça muito poucas distinções categoriais sintáticas para excluir o contra-senso (nonsense). Em uma linguagem corretamente construída pseudo-enunciados não poderiam sequer ser construídos - pois seria imediatamente evidente que símbolos estariam sendo unidos de maneiras ilícitas. Assim, a metafísica não poderia sequer ser expressa em uma linguagem logicamente construída. Um exemplo de como o contra-senso metafísico pode ser gerado, e por que é um contra-senso, é dado pela notória passagem de Heidegger sobre o "nada" em seu ensaio O que é Metafísica?, que culmina no pronunciamenteo de que "o Nada se nadifica" Carnap continuou a anatomizar essa passagem, focalizando com efeito devastador o mal-uso do quantificador negativo.

Carnap enfatizou a diferença entre suas críticas da metafísica e aquelas de filósofos anteriores. A metafísica não é mera especulação, contos de fadas, superstição ou hipóteses de trabalho, nem é inverificável por nós, mas talvez verificável por um ser superior. Antes, ela consiste em nada mais que pseudo-enunciados, isto é, combinações de palavras carentes de significado. A maioria das confusões da metafísica tem origem nas faltas lógicas que infectam o uso do verbo "ser" que Carnap ilustrou com relação ao cogito. 
O que se segue de "Eu penso" não é "eu existo" ou "eu sou", que é mal formado, mas somente "há alguma coisa que pensa". Outra fonte primária de carência de significado é a confusão de tipos de conceitos.

Enunciados significativos são ou tautologias (juízos analíticos), que são verdadeiros em virtude de sua forma, e não dizem nada sobre a realidade - essas são as fórmulas da lógica e das matemáticas - e suas negações, que são contradições, ou enunciados empíricos verdadeiros ou falsos que pertencem ao domínio da ciência. Proposições significativas cognitivamente estão portanto restritas às proposições empíricas. Não pode haver conhecimento da realidade derivável do puro pensamento ou da pura intuição sozinhos, independentemente da experiência. Nem pode haver qualquer conhecimento derivado da experiência, mas transcendendo-a, tais como as hipóteses neo-vitalistas da presença diretora de uma "enteléquia" em processos orgânicos. Finalmente, realismo, idealismo, solipsismo e fenomenalismo são igualmente doutrinas metafísicas carentes de significado. (Carnap não argumenta a favor dessa tese em seu artigo, tendo já feito isso em seu "PseudoProblemas da Filosofia" Neste, seu argumento era o de que não há diferença empírica verificável entre essas doutrinas.)

A verdadeira tarefa da filosofia não é a construção de teses metafísicas ou ontológicas a respeito da natureza do mundo e do que existe nele - essa é a província da ciência e é expressa por proposições empíricas que satisfazem os critérios de significatividade. Antes, a tarefa da filosofia é a de eliminar pseudo-proposições, clarificar conceitos e proposições significativos e, por esse meio, estabelecer os fundamentos para a ciência fatual e para as matemáticas. O método da filosofia é a análise lógica da linguagem.

Se esse veredito condenatório está justificado, então parece um mistério que tantos pensadores distinguidos dedicaram suas vidas à metafísica e é igualmente misterioso, se na realidade eles não estivessem dizendo nada, que eles tenham tido uma tal influ- 
ência. Mas, Carnap concluiu, seus escritos não careciam completamente de conteúdo. Eles careciam de conteúdo empírico e teórico, pois os pseudo-enunciados da metafísica não descrevem estados de coisas. Entretanto, eles efetivamente têm um papel. Eles servem para expressar uma atitude diante da vida, uma Lebenseinstellung ou Lebensgefühl. O metafísico acredita que ele está lidando com um domínio em que enunciados verdadeiros ou falsos descrevem como as coisas são. Mas, de fato, ele não assere nada. Em vez disso, ele expressa alguma coisa, como um artista. Metafísicos são como músicos, só que sem habilidade musical.

\section{O pano-de-fundo do Tractatus}

$\mathrm{Na}$ "Eliminação da Metafísica", Carnap notou que "Para a concepção lógica e epistemológica que está na base de nossa exposição ... cf. Wittgenstein, Tractatus Logico-Philosophicus, 1922, e Carnap, Der Logische Aufbau der Welt, 1928." Escrevendo cerca de trinta anos depois, em sua "Autobiografia Intelectual" publicada no volume de Schilpp, ele escreveu:

"O desenvolvimento mais decisivo em minha visão da metafísica ocorreu depois, no período de Viena, principalmente sob a influência de Wittgenstein. Eu vim a sustentar a visão de que muitas teses da metafísica tradicional não são somente inúteis, mas mesmo desprovidas de conteúdo cognitivo. Elas são pseudo-sentenças, isto é, elas parecem fazer asserções porque elas têm a forma gramatical de sentenças declarativas, e as palavras que ocorrem nelas têm muitas associações fortes e emocionalmente carregadas, enquanto de fato elas não fazem nenhuma asserção, não expressam nenhuma proposição e não são, portanto, nem verdadeiras nem falsas. Mesmo as aparentes questões às quais essas sentenças alegadamente dão uma resposta afirmativa ou negativa, 
por exemplo, a questão "é o mundo externo real?" não são questões genuínas, mas pseudo-questões. A visão de que essas sentenças e questões são não-cognitivas era baseada no princípio da verificabilidade de Wittgenstein. O princípio diz, em primeiro lugar, que o significado de uma sentença é dado pelas condições de sua verificação e, em segundo lugar, que uma sentença é significativa se e somente se é em princípio verificável, isto é, se há circunstâncias possíveis, não necessariamente reais, que, se elas ocorressem, estabeleceriam definitivamente a verdade da sentença. Esse princípio da verificabilidade foi posteriormente substituído pelo princípio mais liberal da confirmabilidade."(2)

É impressionante que quando Wittgenstein viu o Manifesto, ele observou desdenhosamente que não havia nada de novo sobre a "demolição da metafísica" Carnap admitiu que sempre houve críticos da metafísica, mas pensava que todos eles tinham criticado a metafísica como fatualmente falsa, ou como incerta, ou como irrelevante para qualquer assunto prático. $\mathrm{O}$ que lhe parecia novo com relação à sua crítica e do Círculo (e presumivelmente sobre a crítica de Wittgenstein no Tractatus da qual ela era derivada) era o argumento que pretendia mostrar que os proferimentos metafísicos eram carentes de significado. Mas isso não era nenhuma novidade. Hume já tinha argumentado que

"se tomarmos em nossas mãos qualquer volume, de divindade ou metafísica escolástica, por exemplo, perguntemos: contém ele algum raciocínio abstrato concernente a quantidade ou número? Não. Contém ele algum raciocínio experimental concernente a questão de fato e existência? Não. Jogue-mo-lo, então, às chamas; pois ele não pode conter nada senão sofisma e ilusão."(3)

Essa é, realmente, uma versão do século XVIII exatamente do mesmo argumento que o próprio Carnap estava propondo, apesar de lhe faltar o aparato do cálculo lógico e a concepção de sintaxe lógica na qual Carnap punha muita ênfase. Similarmente, a crítica de Kant da metafísica transcendente argumentava que a ten- 
tativa de aplicar conceitos para além do domínio da experiência possível resultava em contra-senso. As categorias, Kant argumentou, "admitem somente um emprego empírico e não têm qualquer significado quando não aplicadas a objetos da experiência possível, isto é, ao mundo do sentido."(4) Assim, realmente não havia nada de novo na condenação da metafísica ou metafísica transcendente como contra-senso. E, seguramente, Wittgenstein também já tinha feito isso no Tractatus. Mas a novidade de sua crítica à metafísica não era a de condenar os proferimentos metafísicos como contra-senso. Nem era a sua crítica baseada no Princípio de Verificação, que não ocorre no livro.

O Tractatus tinha argumentado que pretensas proposições metafísicas eram tentativas de descrever necessidades não-lógicas sobre o mundo, a lógica e a linguagem. Mas a única necessidade capaz de ser expressa é a necessidade lógica, que é expressa por meio de tautologias. Tautologias são proposições moleculares que são combinadas de tal maneira por meio de operadores funcionar̀s de verdade que são incondicionalmente verdadeiras, isto é, verdadeiras para cada atribuição possível de valores de verdade para as proposições elementares constituintes. Do mesmo modo, tautologias não dizem nada, pois elas não excluem nenhuma possibilidade. Elas são, portanto, sem-sentido (senseless) (mas não contra-senso), e conhecer uma tautologia não é conhecer nada sobre como as coisas são na realidade. Mas pretensas proposições metafísicas não são tautologias. Elas não são sem-sentido, mas contra-sensos. E elas são contra-sensos porque não se conformam às regras da gramática lógica, isto é, à sintaxe lógica da linguagem (TLP 3.325). A sintaxe lógica exclui as confusões lógicas fundamentais que caracterizam a filosofia pretérita, em particular as confusões da metafísica. Ela as exclui por não usar o mesmo signo para diferentes símbolos (por exemplo, por usar diferentes signos para identidade, cópula e existência - diferentemente do "é" da linguagem natural) e por não usar em uma maneira superfi- 
$+\quad$ 
ma, isto é, pela variável, da qual o predicado de cor é uma instância substituta. Portanto, de acordo com o Tractatus, proferimentos metafísicos são realmente contra-sensos, mas não porque não há necessidades metafísicas. Antes, as formas necessárias da realidade são inefavelmente mostradas pela linguagem.

Em segundo lugar, as pseudo-proposições da metafísica pretendem enunciar verdades necessárias. Assim, se, per impossibile, elas fossem proposições, elas não seriam bipolares, isto é, não seriam capazes tanto de serem verdadeiras quanto de serem falsas - o que é uma marca de uma proposição com um sentido (por contraste com as proposições sem-sentido da lógica). Asserções metafísicas, incluindo aquelas do autor do Tractatus, aparentemente asserem verdades necessárias não-lógicas, tais como "O mundo consiste em fatos, não em coisas" ou "Fatos são concatenações de objetos", ou "Objetos são a substância do mundo" Mas isso não pode ser feito. O que o metafísico esclarecido, como o autor do Tractatus, perceberá é que os aspectos essenciais e formais do mundo são mostrados pelas sentenças bem formadas da linguagem, por proposições com um sentido e pelas proposições semsentido (mas não contra-sensuais) da lógica. Portanto, a conclusão dramática e paradoxal do Tractatus de que as sentenças do livro são tentativas contra-sensuais de dizer o que não pode ser dito, mas é mostrado. ${ }^{(5)}$

O que, então, com respeito à sua eliminação da metafísica Carnap tirou do Tractatus, o que ele rejeitou e o que ele interpretou mal? Ele aceitou a afirmação de Wittgenstein de que a única necessidade é a necessidade lógica, mas, contra as intenções de Wittgenstein, ele tomou-a au pied de la lettre, pois ele negou que existam quaisquer necessidades inefáveis. Ele aceitou a afirmação de Wittgenstein de que as proposições da lógica são tautologias, que as tautologias não dizem nada (são sem-sentido) e, portanto, que a lógica não é uma expressão de conhecimento. Mas ele rejeitou a visão de que as proposições da lógica representam ou mos- 
tram a armação do mundo (TLP 6.124), que a lógica é uma imagem-espelho do mundo e que ela é "transcendental" (TLP 6.13). E ele pensou que Wittgenstein tinha mostrado que as proposições da lógica são verdades que se seguem de definições arbitrárias dos operadores lógicos, isto é, conseqüências de convenções. Mas essa não era a visão de Wittgenstein, que era antes a de que as proposições da lógica se seguem da natureza essencial da proposição elementar como tal, isto é, de sua bipolaridade essencial. ${ }^{(6)}$ Ele rejeitou a metafísica do simbolismo de Wittgenstein de acordo com a qual somente nomes simples podem representar coisas simples, somente relações podem representar relações e somente fatos podem representar fatos ${ }^{(7)}$ Portanto, por implicação, ele rejeitou a razão peculiar de Wittgenstein para aderir ao princípio contextual de Frege de que uma palavra tem significado somente no contexto de uma sentença, a saber, de que somente em uma sentença - isto é, um fato que simboliza - que uma palavra (nome) substitui um objeto, isto é, tem um significado( ${ }^{(8)}$ Ele supôs equivocadamente que Wittgenstein sustentou que as proposições das matemáticas são ou são redutíveis às tautologias da lógica. Ele também supôs que o Tractatus propôs o Princípio de Verificação, que ele tinha ouvido Wittgenstein (ou Waismann, ao repetir as opiniões de Wittgenstein) defender em conversação. Como notado acima, o Princípio não é explicitamente enunciado no Tractatus, apesar de não ser muito equivocado ver alguma versão dele como implícita no livro. Ele aceitou a tese da extensionalidade e a concepção, também defensavelmente implícita no livro, de que os significados dos nomes simples são dados na experiência. Portanto, também, que todas as proposições são redutíveis a proposições descrevendo o que é assim dado ${ }^{(9)}$ E ele aceitou a visão de que não há proposições filosóficas, mas somente elucidações filosóficas de proposições não-filosóficas e denúncias do contra-senso metafísico. Como ele mais tarde se expressou: "a lógica da ciência assume o lugar do emaranhado inextricável dos problemas que 
é conhecido como filosofia." (10) A lógica da ciência consiste na sintaxe lógica das sentenças, termos, conceitos, teorias etc. da ciência - "ciência" sendo construída, como no Tractatus, como a totalidade das proposições empíricas.

O que Carnap não aceitou foi a sugestão de que a metafísica é inefável. Na verdade, a idéia de que há "verdades" metafísicas que são mostradas pela linguagem mas não podem ser enunciadas era uma afirmação que ele rejeitou vigorosamente. Portanto, a razão que Carnap deu para a eliminação não era a de que as pseudoproposições da metafísica empregam conceitos formais como se eles fossem conceitos genuínos, enquanto eles são na realidade variáveis. Nem ele afirmou que tais supostas proposições não seriam bipolares e, portanto, careceriam de sentido. Antes, seu argumento era o de que as expressões chaves ocorrendo em supostas proposições metafísicas são carentes de significado seja porque não lhes foi atribuído nenhum significado que se pode analisar até o dado, seja porque elas são derivadas de palavras que têm significado mas não são empregadas com esse significado e não se lhes deu nenhum outro significado. Alternativamente, as pseudo-proposições da metafísica contém palavras significativas ilicitamente combinadas, isto é, combinadas de uma maneira tal que não se conformam com as regras da sintaxe lógica e assim, por exemplo, envolvem confusões de tipo lógico. A esses respeitos, o argumento de Carnap realmente converge com o de Wittgenstein, embora não seja o mesmo.

É curioso que, em seu artigo, Carnap não tenha discutido as proposições do Tractatus, por exemplo, que o mundo consiste em fatos e não em coisas, que um é um número, ou que vermelho é uma cor, como exemplos de proposições metafísicas. Sua atenção estava focalizada primariamente nas asserções sobre o Absoluto, Deus, "coisas-nelas-mesmas", as alegadas propriedades e atividades do Nada etc. Foi somente em A Sintaxe Lógica da Linguagem que Carnap dirigiu-se às teses de Wittgenstein sobre a inefabilidade. 

catenação] de objetos" é intencionada para indicar parte da natureza essencial dos fatos, isto é, aspectos de um fato sem os quais ele não seria um fato de maneira nenhuma, e não enunciar alguma coisa sobre a natureza essencial das sentenças ou proposições.

4. Defeitos no argumento de "A Eliminação da Metafísica"

Carnap não deu uma caracterização satisfatória do que é uma asserção metafísica. Afinal, nem toda sentença inverificável pode ser caracterizada assim. Sentenças éticas e estéticas, de acordo com Carnap, são igualmente inverificáveis, mas certamente não devem ser caracterizadas como "metafísicas" "O número três é casado" é, seguramente, um contra-senso, como também o é "idéias verdes dormem furiosamente" - mas elas não pretendem ser asserções metafísicas. Similarmente, Carnap não circunscreveu que tipos de expressões ele julgava ser "metafísicos" Tudo o que ele fez foi indicar que algumas expressões legítimas, tais como "princípio" e "Deus" (em seu uso mitológico), são usadas ilegitimamente pelos metafísicos e ele deu uma lista de outras expressões que são termos metafísicos sem qualquer significado. Mas nem todo mal-uso de uma expressão legítima é "metafísico" e nem todo termo de arte mal-definido ou indefinido é um suposto termo metafísico.

Em segundo lugar, o ímpeto do ataque de Carnap depende da afirmação de que proferimentos metafísicos não passam no teste da verificabilidade. Eu não vou repetir os escrúpulos que surgiram com relação ao Princípio de Verificação e suas modificações desde os dias de Carnap. Independentemente da justificabilidade ou injustificabilidade do Princípio, um ponto óbvio destaca-se. Os filósofos que dizemos que estão engajados na metafísica não sustentam que suas afirmações são validadas pelas experiência. Ao contrário, eles tipicamente sustentaram que elas são validadas por 
um argumento a priori. Platão argumentou que as formas existem e realmente devem existir, uma vez que somente se há formas podem a predicação, a posse de propriedades comuns e o conhecimento de verdades eternas se tornarem inteligíveis. Locke sustentou que deve haver substâncias materiais nas quais as qualidades são inerentes, porque somente assim pode o caráter de nossa experiência se tornar inteligível. Tais metafísicos não ficariam impressionados com o argumento de que suas afirmações, por exemplo, sobre a existência das Formas, da substância material, de uma res cogitans ou de Deus, ou sobre a necessidade de que cada evento deve ter uma causa, ou de que substâncias devem existir uma vez que qualidades são necessariamente inerentes em alguma coisa ou porque deve haver um permanente na percepção, não podem ser confirmadas ou disconfirmadas por qualquer evidência empírica. Se essas afirmações devem ser refutadas, eles teriam insistido, então somente demonstrando, a priori, que há defeitos nos argumentos que as suportam. A concepção platônica de uma Forma, a concepção cartesiana de uma res cogitans, ou a concepção lockeana ou kantiana de substância podem ser incoerentes mas a existência de tais itens foi sustentada por argumentos e são esses que devem ser examinados e refutados pelo anti-metafísico.

O Princípio de Verificação foi posto em dúvida (não menos pelo próprio Carnap em anos posteriores). Assim também sua afirmação de que todos os conceitos devem ser redutíveis por análise a conceitos que se referem diretamente ao dado. O quadro que Carnap pintou era um herdeiro direto da noção empirista clássica de que todas as palavras (que não as expressões sincategoremáticas) significam ou idéias simples ou complexas e que as últimas são definíveis em termos das primeiras, que devem ser dadas na experiência. A concepção de Carnap estava exatamente tão errada quanto a velha doutrina. É eminentemente discutível que palavras para conceitos "substituem" ou "referem-se" a alguma coisa no sentido em que se poderia dizer que nomes próprios substituem ou se 
referem. $O$ fato de que muitas palavras são explicáveis ostensivamente não implica que elas substituam a amostra por referência à qual seu uso é explicado. E que um vasto espectro de palavras e tipos de palavras não são explicados ostensivamente não implica que elas são redutíveis por meio de definições explícitas a tais palavras assim definidas. Portanto, a condenação generalizada de Carnap dos termos característicos dos metafísicos como não cumprindo os padrões exigidos de significância, uma vez que eles não são redutíveis a termos que se referem ao dado, é pouco convincente e demasiado geral. Talvez nada se possa fazer com as "Formas", "o Absoluto", "noumena" etc. - mas isso tem que ser mostrado caso a caso. Além disso, está longe de ser óbvio que restrições similares se aplicam aos termos ocorrendo em afirmações metafísicas tais como "Todo evento tem uma causa" ou "O mundo é tudo o que é o caso", que não são intencionadas como afirmações empíricas sobre as contingências do mundo, mas como afirmações não-empíricas sobre as necessidades do mundo. É ainda menos óbvio no caso de proposições não-empíricas, mas também não-analíticas e necessárias como "Nada pode ser vermelho e verde por toda a superfície simultaneamente" ou "O vermelho é mais parecido com o laranja do que com o amarelo"

Similarmente, Carnap pode estar certo em que as controvérsias entre realismo, idealismo, idealismo transcendental e solipsismo não fazem diferença para qualquer experiência possível. Ele seguramente está certo em dizer que essas não são teorias que podem ser confirmadas ou rejeitadas pela experiência. Elas não são intencionadas para serem teorias do mesmo nível que as teorias científicas. Elas pretendem ser teorias metafísicas sobre aspectos necessários da realidade. Talvez não exista, e não possa existir, uma tal teoria e uma tal coisa. Mas somente mostrar que elas não são nem confirmáveis nem falseáveis pela experiência e não fazem diferença para qualquer experiência possível avança muito pouco para explicar por que o que os metafísicos estavam tentan- 
do fazer é não impossivelmente difícil, mas impossível - porque não há tal coisa para fazer. A condenação generalizada com base nessas razões iluminam pouco o empreendimento que leva a tais doutrinas. Essas doutrinas metafísicas podem ser, como Carnap sustentou, profundamente confusas - mas então nós precisamos entender a confusão e suas fontes. Pois essas doutrinas não são propostas fortuitamente. Elas eram respostas a questões conceituais e, se são respostas equivocadas, nós seguramente precisamos localizar as dificuldades no caráter das questões. E isso não é alcançado pela sua rápida rejeição como empiricamente vácuas.

Se Carnap estava ou não certo em que o que ele chamava de "pseudo-sentenças metafísicas" são contra-sensos, é implausível afirmar que elas servem meramente para expressar uma atitude diante da vida. Quando Platão argumentou em favor das Formas, quando Locke argumentou que devem existir substâncias materiais, quando Berkeley argumentou que Deus deve existir como causa de nossas idéias e como percipiente de idéias não percebidas por nós, quando Leibniz argumentou em favor da existência de mônadas, eles seguramente não estavam engajados na expressão de atitudes poéticas diante da vida. Antes, eles estavam tentando resolver questões filosóficas e conceituais profundamente enigmáticas. Suas questões podem bem ser equivocadas, já incorporando confusões conceituais, que por sua vez infectam suas respostas. Suas soluções propostas podem bem ser contra-sensos em vez de falsas - mas de qualquer maneira não poesia feita no lugar errado.

Não se pode duvidar de que Carnap e outros membros do Círculo obtiveram sucesso em levantar suspeitas sobre o que era concebido como afirmações metafísicas. As observações críticas de Carnap indicam a mudança na filosofia analítica de supostas investigações sobre questões da verdade para investigações sobre questões de significado - uma mudança que era anunciada pelo Tractatus de Wittgenstein ${ }^{(11)}$ e posteriormente se tornou conheci- 
da pela descrição "a virada linguística", de Gustav Bergmann. Isso levou a uma investigação crítica salutar sobre os significados, se há algum, das afirmações características feitas pelos metafísicos do passado. Mas os próprios argumentos de Carnap contra a inteligibilidade das afirmações metafísicas eram muito gerais e repousavam em razões muito inseguras para justificar a condenação crítica que ele advogava.

\section{A volte face de Wittgenstein}

Essencial para o argumento de Carnap era a idéia de que as únicas sentenças significativas são ou proposições da lógica (tautologias ou contradições), que não dizem nada, ou proposições empíricas, que são verificáveis ou falseáveis na experiência. Todas as outras sentenças são contra-sensos, ou - menos ofensivamente - carecem de significado cognitivo. Isso inclui sentenças da ética, estética e religião, bem como as pseudo-sentenças da metafísica.

A ironia do assunto era que precisamente no mesmo momento em que Carnap estava propondo suas visões anti-metafísicas inspiradas no Tractatus, Wittgenstein estava mudando de opinião sobre as afirmações feitas no Tractatus e desenvolvendo uma crítica muito diferente da metafísica. O resultado de suas reconsiderações foi o seguinte ${ }^{(12)}$. O conceito de uma proposição, contrariamente ao que ele tinha argumentado no Tractatus, é um conceito de semelhança de família. Muitos tipos diferentes de estruturas linguísticas são chamadas de "proposições" e elas estão unidas não por uma essência comum, mas por similaridades que se sobrepõem. A bipolaridade é um aspecto importante de alguns membros da família, mas não de todos. Era um dogmatismo negar às equações da aritmética (ou aos teoremas da geometria) o esta- 
tuto de proposições. O que era verdade era que eles são tipos muito diferentes de estruturas das proposições empíricas (elas próprias muito mais diversas em tipo do que ele tinha admitido), com um tipo fundamentalmente diferente de papel. Pois as proposições matemáticas verdadeiras são expressões de normas de representação, não descrições de estados de coisas ou tautologias. Similarmente, aquelas proposições do Tractatus que são defensáveis, mas que eram condenadas como tentativas de dizer o que não pode ser dito mas é mostrado, não são pseudo-proposições. Antes, elas são proposições gramaticais, isto é, expressões de regras para o uso de conceitos constituintes expressos pelas palavras da própria proposição ela mesma. É perfeitamente lícito asserir que vermelho é uma cor ou que um é um número. Tais sentenças não são pseudo-proposições mal formadas. Tais como concebidas no Tractatus, elas eram tentativas de enunciar aspectos da essência de seu assunto (vermelho ou um). Isso estava em parte confuso, em parte correto. O que estava confuso era a idéia de que as essências das coisas são aspectos (formas) das coisas independentes da linguagem, que são refletidas nas formas lógico-sintáticas da linguagem. Mas é a gramática que determina o que nós enganosamente estamos inclinados a chamar de "a essência" das coisas, isto é, suas propriedades e relações definidoras. Não é a propriedade de um objeto que é sempre "essencial", mas a marca de um conceito. A aparência de necessidades de re (propriedades essenciais) é meramente a sombra lançada pela gramática sobre o mundo. A proposição "metafísica" de que vermelho é uma cor é normativa. Ela permite-nos inferir da proposição de que A é vermelho a proposição de que A tem uma cor (ou é colorido). Tais proposições são expressões de regras sob o disfarce enganoso de descrições super-empíricas da natureza das coisas independente da linguagem. Similarmente, pace o Tractatus, não há nada de errado em dizer que a proposição ( $\mathrm{p} \&(\mathrm{p}>\mathrm{q}))>$ q é uma tautologia. Não é, seguramente, uma proposição bipolar. Ela aparentemente 
enuncia uma propriedade essencial e interna da proposição em questão. Mas, de novo, é de fato a expressão de uma regra. Isto é, a proposição tautológica não diz nada, mas dizer dessa proposição que ela é uma tautologia é expressar uma regra, a saber, que "q" pode ser inferido de " $p$ " e "p $>$ q"(13) Pois toda tautologia é correlata a uma regra de inferência. Reconhecer a tautologia é ipso facto admitir a regra de inferência e reconhecer a regra de inferência é admitir a proposição como uma tautologia.

Naturalmente, nem todas as proposições do Tractatus eram como essa. A afirmação de que o mundo consiste em fatos e não em coisas, por exemplo, era um enunciado equivocado da proposição gramatical correta de que a descrição do mundo consiste em um enunciado de fatos e não em uma lista de coisas. E essa proposição não é mais do que uma regra que determina o conceito de uma descrição. Outras afirmações eram realmente contra-sensos, na medida em que elas não são de maneira nenhuma normas de representação "vistas obscuramente através de um vidro" A afirmação (alegadamente inefável) de que fatos eram concatenações de objetos, ou de que fatos consistem em objetos, não é uma tentativa de dizer alguma coisa que é mostrada por enunciados fatuais. Ela não é uma proposição gramatical "verdadeira" Nem é ela uma proposição empírica verdadeira ou falsa. É um mero contra-senso. O que pode ser dito é que fatos não consistem em nada, não têm objetos como seus constituintes - e essa é uma proposição gramatical correta. Ela diz que não há uma coisa tal como um fato que tem constituintes, isto é, que a forma das palavras "O fato de que $p$ tem $a$ e $F$ como seus constituintes" não tem uso, que é carente de significado.

A última proposição gramatical poderia ser expressa por uma proposição modal, por exemplo, fatos não podem ter objetos como constituintes. As proposições que tradicionalmente são julgadas como metafísicas são freqüentemente postas na forma modal, caracterizando o que é necessariamente assim, o que é essencial- 

à sua intuição. As afirmações de que deve haver Formas platônicas, ou substâncias lockeanas, ou mônadas leibnizianas são diferentemente confusas. Pois seus argumentos parecem ser análogos às inferências científicas que partem do observado para o inobservável, por exemplo, hipóteses científicas concernentes à existência de partículas sub-atômicas ou genes. Mas hipóteses científicas genuínas são tentativas de explicar um fenômeno empírico. Explicações desse tipo têm conseqüências empíricas adicionais, muitas das quais podem não ter sido predizíveis de início (não se podem ver partículas sub-atômicas, mas pode-se descobrir sua carga elétrica, pesá-las, medir sua velocidade etc.). O metafísico imita os procedimentos do cientista. Mas o que ele procura explicar não são de maneira nenhuma fenômenos empíricos, mas enigmas conceituais mascarados como tais (por exemplo, como a predicação é possível, ou como pode haver instâncias de uma propriedade comum; ou como pode uma coisa reter sua identidade através da mudança; ou a que entidade as experiências pertencem), enigmas que já incorporam confusões conceituais. Além disso, as entidades em que ele insiste devem existir e as teorias que ele propõe em apoio das suas afirmações existenciais não têm conseqüências adicionais e empiricamente confirmáveis. Pois elas não são de maneira nenhuma teorias genuínas, mas são meramente afirmações conceituais confusas.

"A Eliminação da Metafísica", junto com outros escritos antimetafísicos de Carnap, sustentado pelos escritos de outros membros do Círculo (incluindo Ayer) e também pelos ensinamentos de Wittgenstein em Cambridge, colocaram a própria palavra "metafísica" no Index da filosofia analítica pelos próximos trinta anos ou mais ${ }^{(14)}$. Foi amplamente aceita entre a geração mais jovem de filósofos analíticos a tese de que a metafísica é filosoficamente de má reputação. Apesar de tentativas de reabilitar ou reinterpretar os esforços metafísicos do passado por filósofos tais como Collingwood, Wisdom e Lazerowitz, houve poucos filósofos pre- 


\section{Notas}

(1) Voltaire observou belamente que os metafísicos "são como bailarinos de minueto, que, estando vestidos da melhor maneira, fazem um par de reverências, movem-se pela sala nas atitudes mais finas, exibem todas as suas graças, estão em movimento perpétuo sem avançar um passo e terminam no mesmo ponto de que partiram." Para Hume, veja abaixo, nota 4.

(2) R. Carnap, "Intellectual Autobiography" in P.A. Schilpp ed., The Philosophy of Rudolf Carnap, (Open Court, La Salle, Illinois, 1963), p. 44.

(3) Hume, An Enquiry Concerning Human Understanding, Sect. XII, Part III, parágrafo final.

(4) Kant, Critique of Pure reason, B 724. É claro que é verdade que Kant veio a violar seus próprios princípios em suas discussões dos noumena e sua relação com os phenomena.

(5) Elas são contra-sensos, mas não melhores logicamente do que qualquer outro contra-senso, pois não há tipos logicamente diferentes ou graus de contra-senso. Mas elas são, entretanto, diferentes de meros grunhidos tais como "Ab sur ah" na intenção com a qual elas são proferidas e no papel que elas desempenham. Elas são proferidas na tentativa de dizer alguma coisa que não pode ser dita mas somente pode ser mostrada. E elas são degraus essenciais da escada que se pode subir para atingir um ponto de vista lógico correto.

(6) Wittgenstein argumentou que toda proposição com um sentido é capaz de ser verdadeira e capaz de ser falsa. Mas "É verdade que p" = "p" e "É falso que p" = "não-p". Assim, a negação é dada com a mera idéia de uma proposição como tal. E a conjunção é dada pela mera possibilidade de asserção sucessiva. E se a negação e a conjunção são dadas, então assim também são dados todos os operadores lógicos. Pois todos eles são redutíveis à operação da negação conjunta. Se todas as proposições elementares são dadas, então todas as proposições são dadas, uma vez que todas as proposições possíveis, incluindo todas as proposições da lógica, podem ser geradas pela operação da negação conjunta sobre conjuntos de proposições elementares.

(7) De acordo com o Tractatus, uma sentença que expressa um sentido faz isso em virtude de ser um fato, isto é, é o fato de que os signos, nos quais 
na causou um grande impacto em minha geração e na próxima geração de filósofos. A maioria de nós aceitou de maneira pouco trágica sua demolição da metafísica. Afinal de contas, nós nunca tínhamos encontrado ninguém engajado em quaisquer compromissos metafísicos; nossas cópias de Aparência e Realidade estavam empoeiradas; e a maioria de nós jamais tinha visto uma cópia de Sein und Zeit." "Autobiographical" in O.P. Wood and G. Pitcher (eds.), Ryle: A Collection of Critical Essays (Doubleday \& Company, Inc., Garden City, New York, 1970), pp. 9 s. 